\section{En morsom og fengende plate for liten og stor}



\author{
Trygve Kongshavn \\ For liten og for stor \\ CD 40,33 min. Oslo: daWorks Records, 2013 \\ Pris NOK 139 \\ ESS-DACD693
}

Det finnes mange kreative leger, og noen går lenger enn andre med sine kunstneriske utfoldelser. Trygve Kongshavn er fastlege, og nå også barnemusiker. Han har utgitt en CD for barn, og jeg har fått den hyggelige oppgaven å anmelde denne. Kongshavn har fått solid følge på den musikalske delen, med særdeles dyktige musikere fra bandet «Something Sally», der også hans sønn spiller.

Jeg kan ikke påberope meg lang erfaring med musikkanmeldelser, men jeg har antakelig blitt spurt om å anmelde denne CD-en $i$ kraft av at jeg selv er lege, har flere barn og er generelt interessert i musikk. I sommer har jeg derfor brukt mine barn og deres venner som bidragsytere i vurderingen av denne CD-en. Målgruppen er selvsagt barn, og da må barna få mene noe om denne utgivelsen! «Testpanelet» har bestått av barn i aldersgruppen fra 1,5 til 7 år.

Det er så å si ingenting å utsette på det musikalske. Sangene er melodiøse, fengende og utrolig godt instrumentert. Det musikalske uttrykket er variabelt. Det er derfor vanskelig å karakterisere CD-en som en spesifikk stil, men flere av sangene får en til å trekke paralleller mot for eksempel Knutsen og Ludvigsen, Odd Nordstoga, Bjørn Eidsvåg, Ole Paus og Øystein Sunde. Det er rocka sanger, fengende popsanger, morsomme sanger, rolige sanger og noen rare sanger.

Akkordsammensetningene og melodiene er relativt enkle, med kjente strofer, uten spissfindige krumspring. Samtidig har Kongshavn, med meget god støtte fra bandet, klart å lage musikken alt annet enn kjedelig, og den oppfattes ikke som enkel på noe som helst vis. Melodiene er lette å huske, og det gjør selvsagt at barna lett stemmer i etter å ha hørt sangene noen ganger. Med en annen tekst kunne flere av melodiene glidd rett inn på en voksenplate dette er en plate for liten og for stor!

Tekstene tar for seg svært gjenkjennelige temaer som de fleste barn (og småbarnsforeldre) interesserer seg for. De handler om bading, dyr på gården, telling, biler, strenge voksne, hvor utfordrende det kan være å kle på seg, god natt-sang, og ikke minst om æsj, bæsj, promp og fis. Personlig synes jeg enkelte av tekstene bærer preg av litt for enkel lyrikk og rim, men de er lette å huske og fengende for barna - og det er det viktigste.

Av høydepunkter må jeg selvsagt trekke frem «Æsj, bæsj, promp og fis»! Jeg har ikke tall på hvor mange ganger denne er blitt spilt i løpet av sommeren. Andre høydepunkter for barna har vært «Alle de gravide menn», «Bare du og jeg» og «Tellesangen».

Dette er en CD jeg helt klart kan anbefale småbarnsforeldre å skaffe seg. Det er mye glede i god musikk, og mitt barnetestpanel kunne ikke vært mer enig!

Øystein Sverdrup

Lege i spesialisering, Mikrobiologisk avdeling

Sykehuset i Vestfold

\section{Et konsentrat av prinsipper i New public management-tenkningen}

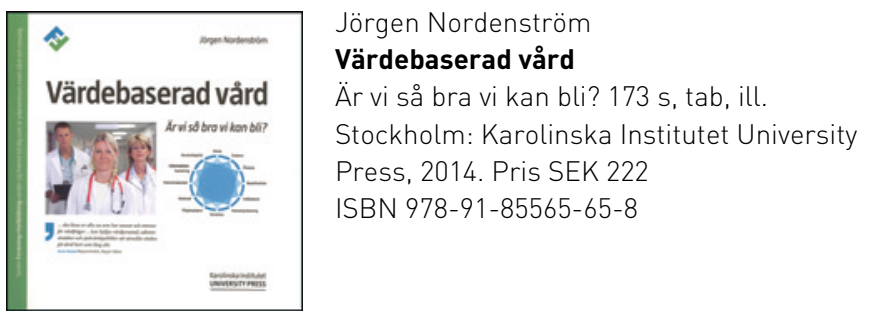

«Boken är avsedd för alla som är verksamma innom vården, i första hand läkare och sjuksköterskor men även administrativa medarbetare och chefer.» Den gir en grei og verdifull gjennomgang av kvalitetssikringsmetoder og terminologi, samt måter å objektivere drift og resultater i sykehus på. Tittelen kan misforstås dit hen at det dreier seg om myke verdier som etikk, kultur og menneskeverd. Det gjør det ikke. Det er her kun snakk om harde endepunkter som økonomi, budsjett, innsparinger og målbare kvalitetsforbedringer. Forfatteren siterer, uten å kommentere, en feilaktig påstand: «Det man inte kan mäta, kan man heller inte förbättra.» Boken er ikke en komplett lærebok, men et konsentrat av prinsipper i New public management-tenkningen.

Boken får plass i frakkelommen. Språket er svensk. Den har stikkordregister, litteraturliste samt flere relevante internettadresser. Boken inneholder mye informasjon, og det er greit å finne frem i den.

Det gis eksempler på store økonomiske innsparinger som også ga kvalitetsforbedringer i sykehusene. Forfatterens kobling av økonomiske innsparinger og kvalitetsforbedring kan gi et inntrykk av at det nærmest er to sider av samme sak. Det nevnes ikke at innsparinger kan gi negative konsekvenser. Ei heller at pengesparingskulturen kan ha uheldige sider eller en yttergrense. Forfatteren har helt rett $i$ at registerdata er viktig for kvalitetskontroll. Det er unødvendig og uvitenskapelig å påpeke at de som mener å kunne dokumentere egne resultater som gode, mest sannsynlig tar feil og er rammet av «illusory superiority».

Boken omhandler så å si kun innsparinger og forbedringer som kan gjøres «på gulvet», blant de som gjør kjernearbeidet i sykehusene. Kostnader og konsekvenser av omstillinger og omorganiseringer diskuteres ikke. Forfatteren nevner heller ikke kostnadene og konsekvensene av at en stor og økende andel av ansatte i sykehus ikke gjør pasientrettet arbeid. Når han i en kapitteloverskrift spør «Varför är sjukhus så dyra?», er de stadig voksende sykehusadministrasjoner ikke en del av diskusjonen, og da heller ikke en del av svaret.

Man må altså huske på at denne boken kun omtaler en del av sykehusvesenet. Om leseren også har Arnulf Øverlands ord «Du må ikke gå til ditt kjøpmannskap og tenke på hvad der gir vinning og tap» $\mathrm{i}$ bakhodet, kan boken gi viktig informasjon for god drift av sykehus.

\section{Steinar Solberg}

Overlege, Thoraxkirurgisk avdeling

Oslo universitetssykehus, Rikshospitalet 